\title{
GLANDULAR AND NON-GLANDULAR HAIRS IN THE SEASONALLY DIMORPHIC Origanum dictamnus L. (LAMIACEAE) AS A MEANS OF ADAPTATION TO COLD STRESS
}

\author{
Artemios M. Bosabalidis, Thomas Sawidis \\ Department of Botany, School of Biology, Aristotle University, Thessaloniki 54124, Greece \\ e-mail:artbos@bio.auth.gr
}

Received: 20.11.2013

\begin{abstract}
Origanum dictamnus is a seasonally dimorphic plant having different appearance in winter and summer. Shoots of winter plants are leaf-naked except for their apical region which bears a cluster of small leaves covered with a thick indumentum of non-glandular hairs. This indumentum highly contributes to the avoidance of cold penetration into the leaf mesophyll, allowing thus plants to endure winter low temperatures. Shoots of summer plants are vigorous with large green leaves. Non-glandular hairs are dendroid with a 5-celled vertical stub and several lateral branches. Glandular hairs are of two types, large peltate hairs and small capitate hairs. Peltate hairs are numerous and consist of a 12-celled head, a unicellular stalk, and a basal epidermal cell.. They constitute the sites of essential oil secretion. Capitate hairs occur in a small number and are composed of a unicellular head, a unicellular stalk and a basal epidermal cell. They are not secreting essential oil, but a hydrophilic material. The oil secreted by the peltate hairs has antioxidant properties, opposes the oxidative stress resulted from low temperatures, and contributes to the adaptation of the plant to winter cold stress.
\end{abstract}

Key words: Origanum dictamnus, glandular hairs, non-glandular hairs, adaptation, cold stress

\section{INTRODUCTION}

Origanum dictamnus is an endemic perennial subshrub growing wildly on calcareous cliffs of the island of Crete, S. Greece. The shoots reach a length of $30-40 \mathrm{~cm}$ and bear rounded to ovate leaves arranged in a decussate phyllotaxis. At the apices of the shoots, inflorescences (spikes) develop composed of purple/pink bracts, in the axils of which pink flowers emerge. Shoots, leaves, and flowers bear numerous peltate hairs which initiate at the epidermis from individual protodermal cells [1]. Peltate hairs secrete an essential oil rich in carvacrol [2]. This oil is biosynthesized in the ground plasm of the head cells of the peltate hairs [3] and becomes released into the apical subcuticular chamber in the form of glycosides [4].

O. dictamnus possesses potent biological activities against head and stomach aches, arthritis, inflammation, sepsis, bleeding, ulcer, epilepsy and cancer (leukemia and bronchial epidermoid cancer) $[5,6]$. It has also antimicrobial and antioxidant properties [7] which allow that extracts of the plant can be used as natural food preservatives $[8,9]$.

O. dictamnus is a seasonally dimorphic plant with diverging morphology in winter and summer. In winter, the plant undergoes at the study area oxidative stress due to low temperatures (see MATERIAL AND METHODS). To defend itself against cold stress, $O$. dictamnus sheds its large leaves and develops a dense leaf indumentum of glandular and non-glandular hairs in the small apical leaves. Glandular hairs secrete essential oils which have antioxidant properties, while non-glandular hairs operate as a thick insulating layer which prevents penetration of the cold into the leaf mesophyll. In summer, the plant does not undergo heat/drought stress, because of the prevailing mild weather conditions.

In the present work, the leaf indumentum of O. dictamnus was comparatively studied in winter and summer plants in order to draw conclusions about its possible contribution to the integrated mechanism of adaptation of the plant to cold stress.

\section{MATERIAL AND METHODS}

\section{Plant material and sampling}

Origanum dictamnus L. (Lamiaceae) was studied at the Aromatic Plant Institute, NAGREF, Thessaloniki, N. Greece (N 4054'03”, E 2300'18', altitude 
$16 \mathrm{~m}$ a.s.l.). At this region, the meteorological data in the three years of study (2009-2011) showed that during the winter months the average daily air temperature was $7.9^{\circ} \mathrm{C}$, the average daily air humidity $77.4 \%$, and the average daily rainfall $2.4 \mathrm{~mm}$. During the summer months, the climatic conditions were mild (not hot and dry) with an average daily air temperature of $25.8^{\circ} \mathrm{C}$, an average daily relative air humidity of $60.5 \%$, and an average daily rainfall of $1.0 \mathrm{~mm}$. Meteorological data were provided by the Meteorological Station of the Farm of the Agricultural School, Aristotle University, Thessaloniki, Greece. Winter sampling was performed in January and summer sampling in June. Fully-expanded leaves of annual shoots were used ( $3^{\text {rd }}$ node from the shoot basis).

\section{Microscopy (LM, SEM)}

From a sample of 18 leaves (3 leaves x 6 plants), 5 leaves were randomly selected for light microscopy (LM) and another 5 leaves for scanning electron microscopy (SEM). For LM, pieces from the middle area of the leaves (on either side of the midrib) were prefixed for $3 \mathrm{~h}$ with $5 \%$ glutaraldehyde in $0.05 \mathrm{M}$ phosphate buffer ( $\mathrm{pH} 7.2$ ) and post-fixed for $4 \mathrm{~h}$ with $2 \%$ osmium tetroxide, similarly buffered. Fixed samples were dehydrated in an ethanol series (50-100\%) and finally embedded in Spurr's resin. Semithin sections ( $1 \mu \mathrm{m}$ thick) for LM were obtained with a Reichert Om $\mathrm{U}_{2}$ microtome (Reichert Optische Werke AG, Vienna, Austria), stained with Toluidine Blue $\mathrm{O}$ and observed on a Nikon Eclipse 180 light microscope (Nikon Instruments, Amstelvee, The Netherlands). For SEM, the specimens, after fixation and dehydration, were critical-point dried in a Balzers CPD 030 device (Balzers Union AG, Liechtenstein) and then carbon-coated in a Jeol JEE-4X vacuum evaporator (Jeol Ltd, Tokyo, Japan).Observations were made with a Jeol JSM 840A scanning electron microscope.

\section{Morphometry}

The densities $\left(\mathrm{No} / \mathrm{mm}^{2}\right)$ of glandular and nonglandular hairs on both surfaces of the winter and summer leaves were determined using 36 SEM micrographs. These micrographs were also used for conducting morphometric assessments on the hairs.

\section{Histochemistry}

For the identification of the lipidic nature of the essential oil accumulated in the subcuticular chamber of the glandular peltate hairs, two histochemical tests were applied. The first comprised staining of semithin sections (microtome) with the lipophilic dye Sudan Black B ( $1 \%$ in $70 \%$ ethanol, $\left.50 \mathrm{~min}, 60^{\circ} \mathrm{C}\right)$ [10]. The second comprised staining of free-hand sections with the lipophilic reagent osmium tetroxide ( $2 \%$ aqueous solution, $30 \mathrm{~min}$, room temperature).

\section{Statistics}

Statistical analysis was performed with the SPSS package (SPSS Inc. Chicago, USA) using ANOVA for comparison of means between treatments. Significance was determined at $\mathrm{p} \leq 0.05$ probability level.

\section{RESULTS}

Origanum dictamnus is a seasonally dimorphic plant with entirely different appearance in winter and summer (Fig. 1A, B). Winter plants have erect shoots which are leaf-naked (large leaves are shed) except for their apical region where a cluster of small leaves exists (Fig. 1A). Winter plants in macroscopical view give the wrong impression that they are dry and non-living. Summer plants, on the other hand, are vigorous with large green leaves arranged in a decussate phyllotaxis (Fig. 1B). Both the winter and summer leaves possess glandular and non-glandular hairs, the latter being about twice as dense in the winter leaves (Table 1). Non-glandular hairs are typically dendroid and they are composed of a 5-celled vertical stub developing lateral branches. The stub is much thicker in the winter leaf hairs than in the summer leaf hairs, and also in the adaxial leaf surface hairs than in the abaxial leaf surface ones (Table 1, Fig. 1C). Branches ordinarily appear at the upper 2-3 cells of the hair stub, and they are thin, unicellular, and pointed (Fig. 2F). The surface of the non-glandular hairs is not smooth, but bears scale-like projections (Fig. 2G).

Glandular hairs are of two types, large peltate hairs (Fig. 2C, large arrow) and small capitate hairs (Fig. 2C, small arrow). Peltate hairs are composed of an epidermal basal cell (fc), a stalk cell (sc), and a 12-celled head (hc) (Fig. 2B, C). From the 12 cells of the head, the 4 are small and centrally located and the 8 large and peripherally arranged (Fig. 2B). The essential oil is biosynthesized in the head cells of the peltate hairs and becomes excreted into a chamber formed at the apex of the head between the cell walls and the raised cuticle (Fig. 2C, large arrow). Histochemical tests with Sudan Black B and osmium tetroxide confirmed the presence of essential oil within this subcuticular chamber (Fig. 2D, E). Capitate hairs are composed of an epidermal basal cell, a stalk cell, and a pear-like head cell (Fig. 2C, small arrow). They are not secreting essential oil, but a lipophobic (hydrophilic) material, as histochemical tests with the lipophilic osmium tetroxide showed (Fig.2E, small arrow). 

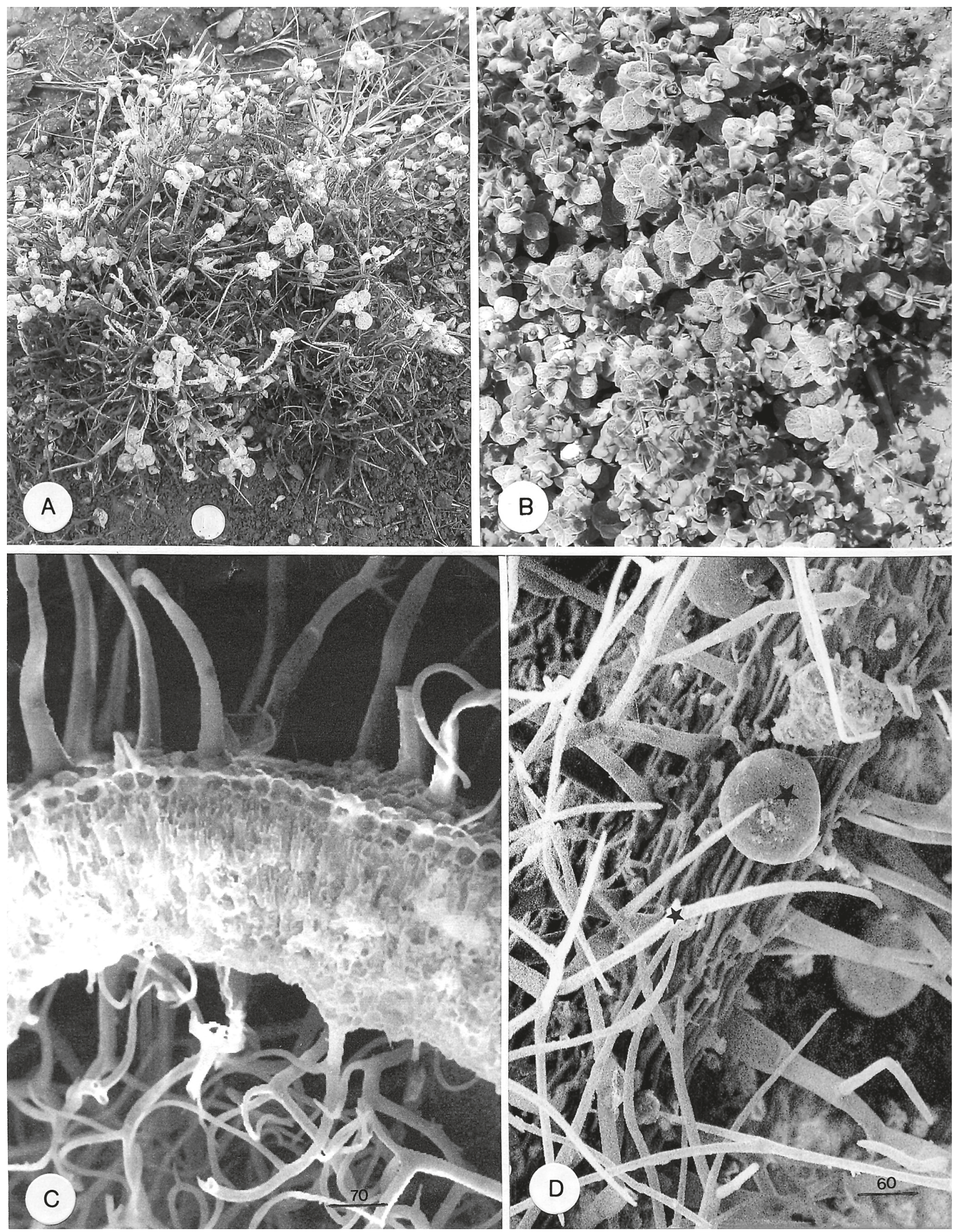

Fig. 1. Origanum dictamnus. Surface view of a winter plant $(\mathrm{A})$ and a summer plant $(\mathrm{B})$ in the field. Coin 1 Euro $=2.4 \mathrm{~cm}$ diam. C. Leaf cross-section illustrating the density and thickness of the non-glandular hairs on the upper and lower leaf sides. D. SEM view of the abaxial leaf surface covered with glandular hairs (large asterisk) and non-glandular hairs (small asterisk). Bars in $\mu \mathrm{m}$. 

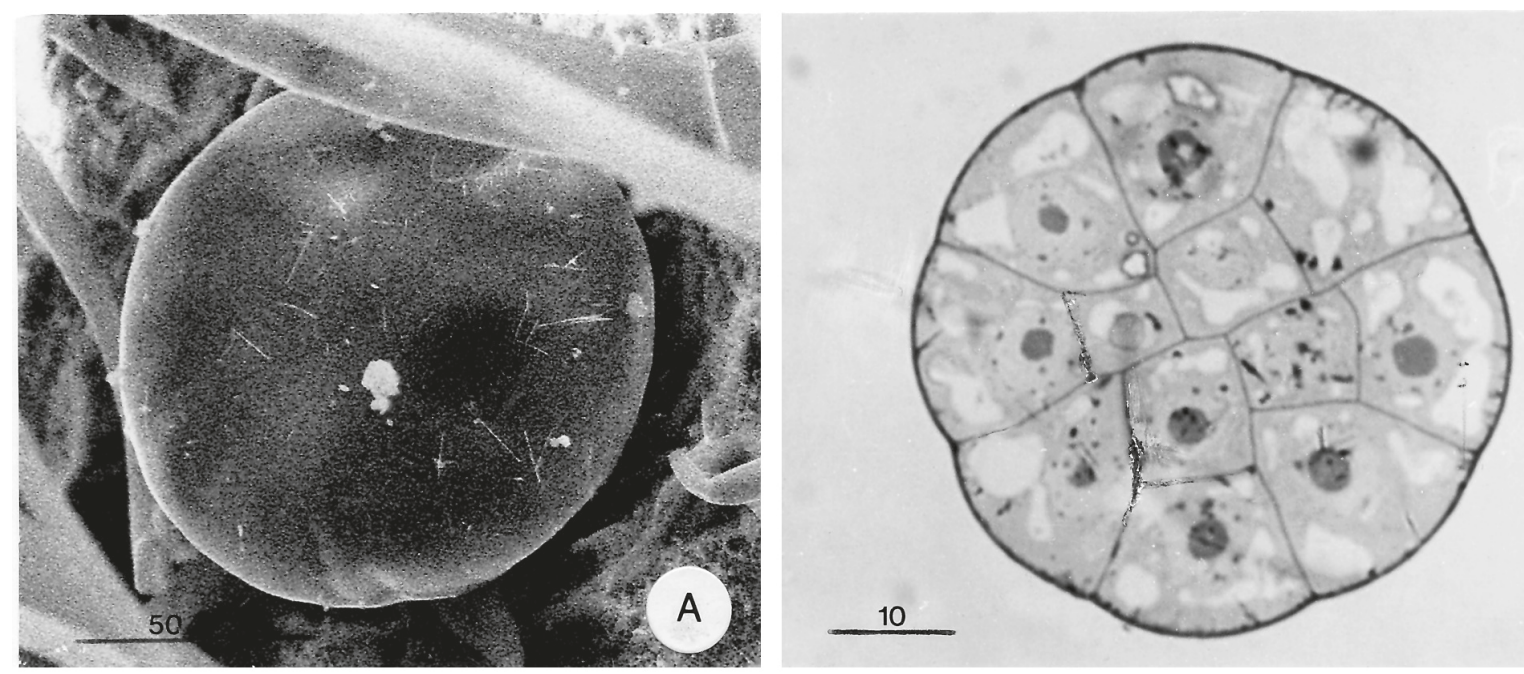

B

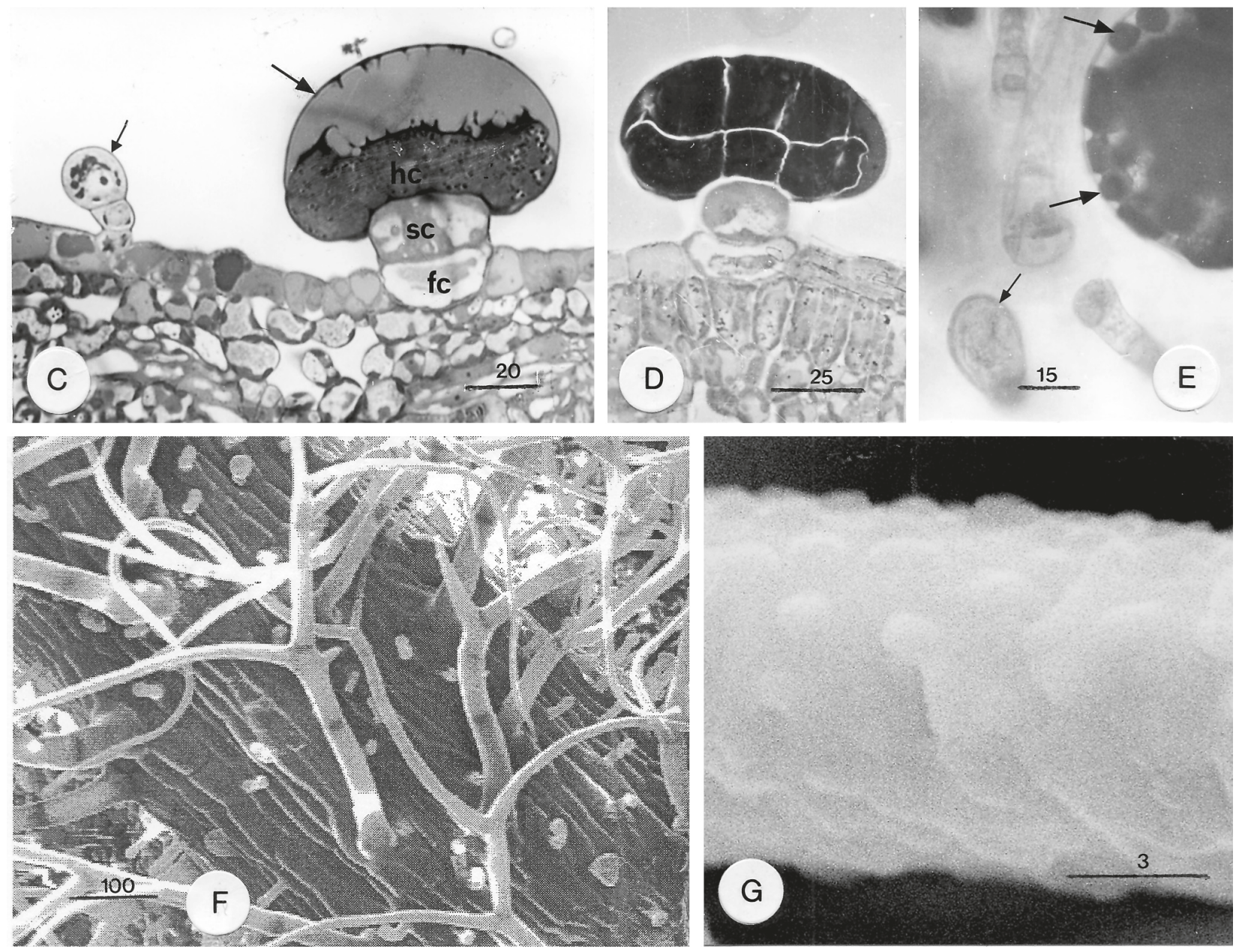

Fig. 2. The head of a peltate glandular hair observed with the SEM (A) and the LM (B). C. Longitudinal section of a capitate glandular hair (small arrow) and a peltate glandular hair (large arrow). The basal region (fc), the stalk region (sc) and the head region (hc) of the peltate hair are indicated. D, E. Histochemical tests with the lipophilic dyes Sudan Black B (D) and osmium tetroxide (E). In both cases, the essential oil contained within the subcuticular chamber of the peltate hairs is stained black. Capitate hairs remained unstained (Fig. 2E, small arrow). F. Dendroid non-glandular hairs on the abaxial surface of the leaf. G. High magnification of a non-glandular hair with visible scale-like projections. Bars in $\mu \mathrm{m}$. 
Table 1

Origanum dictamnus. Morphometric assessments of peltate glandular hairs and dendroid non-glandular hairs in fully -expanded leaves of winter and summer $( \pm \mathrm{SD}, \mathrm{n}=36)$. Means between columns with different letters are significantly different at 0.05 level

\begin{tabular}{lcc}
\hline & Winter leaves & Summer leaves \\
\hline Density of peltate glandular hairs on the upper leaf side $\left(\mathrm{No} / \mathrm{mm}^{2}\right)$ & $3.5 \pm 2.0 \mathrm{a}$ & $4.6 \pm 1.4 \mathrm{~b}$ \\
Density of peltate glandular hairs on the lower leaf side $\left(\mathrm{No} / \mathrm{mm}^{2}\right)$ & $4.8 \pm 1.4 \mathrm{a}$ & $6.1 \pm 1.4 \mathrm{~b}$ \\
Head diameter of peltate glandular hairs in surface view on the upper leaf side $(\mu \mathrm{m})$ & $93.3 \pm 8.6 \mathrm{a}$ & $91.9 \pm 7.3 \mathrm{a}$ \\
Head diameter of peltate glandular hairs in surface view on the lower leaf side $(\mu \mathrm{m})$ & $92.8 \pm 9.9 \mathrm{a}$ & $92.3 \pm 7.8 \mathrm{a}$ \\
Density of dendroid non-glandular hairs on the upper leaf side $\left(\mathrm{No} / \mathrm{mm}^{2}\right)$ & $35.7 \pm 4.6 \mathrm{a}$ & $16.7 \pm 2.1 \mathrm{~b}$ \\
Density of dendroid non-glandular hairs on the lower leaf side $\left(\mathrm{No} / \mathrm{mm}^{2}\right)$ & $78.1 \pm 5.5 \mathrm{a}$ & $41.3 \pm 4.2 \mathrm{~b}$ \\
Thickness of the base of dendroid non-glandular hairs on the upper leaf side $(\mu \mathrm{m})$ & $50.2 \pm 3.8 \mathrm{a}$ & $35.3 \pm 4.7 \mathrm{~b}$ \\
Thickness of the base of dendroid non-glandular hairs on the lower leaf side $(\mu \mathrm{m})$ & $32.9 \pm 5.6 \mathrm{a}$ & $25.1 \pm 3.0 \mathrm{~b}$ \\
Height of dendroid non-glandular hairs on the upper leaf side $(\mu \mathrm{m})$ & $800 \pm 80 \mathrm{a}$ & $1000 \pm 90 \mathrm{~b}$ \\
Height of dendroid non-glandular hairs on the lower leaf side $(\mu \mathrm{m})$ & $600 \pm 100 \mathrm{a}$ & $800 \pm 110 \mathrm{~b}$ \\
\hline
\end{tabular}

\section{DISCUSSION}

Origanum dictamnus plants protect themselves from winter cold stress principally in the following ways :

- They shed all of their large leaves and keep only a cluster of small leaves at the apex of the shoots. The abscission of the large leaves involves activation of the phytohormone abscisic acid (ABA) [11] and reflects a strategy of the plant to avoid exposition to the low winter temperatures of a large foliage surface area (leaf dehydration and necrosis).

- They cover the apical small leaves with a dense indumentum of dendroid non-glandular hairs. This thick indumentum operates as an insulating shield which prevents penetration of the cold into the leaf mesophyll.

- They develop on the apical leaves numerous glandular hairs which secrete a remarkable amount of essential oil [12]. This oil has antioxidant properties [13] and protects from oxidative stress resulted from winter cold.

- The above considerations along with the presented morphological,anatomical, morphometrical, and histochemical observations on the glandular and non-glandular hairs give an enlightening picture as to the mechanism of adaptation of O.dictamnus to winter cold stress. The results may also be useful to application of plant hairs to modern systematics.

\section{Acknowledgements}

Authors wish to thank the University of Thessaloniki for the financial support.

\section{Authors' contributions}

The following declaration about authors' contributions to the research have been made: study conception: $\mathrm{AB}$; field researches and collecting data: $\mathrm{AB}, \mathrm{TS}$; data interpretation: $\mathrm{AB}$, TS; writing of the manuscript, table and figure arrangement: $\mathrm{AB}$.

\section{REFERENCES}

1. Evert RF. Esau's Plant Anatomy: meristems, cells, and tissues of the plant body: their structure, function, and development. Hoboken, NJ: John Wiley \& Sons; 2006.

2. Katsiotis S, Oikonomou GN. Vergleichende Untersuchung verschiedener und in Kreta angebauter Muster von Origanum dictamnus L. Sci Pharm. 1986; 54: 49-52.

3. Bosabalidis A, Tsekos I. Glandular scale development and essential oil secretion in Origanum dictamnus L. Planta. 1982; 156(6): 496-504. http://dx.doi.org/10.1007/BF 00392771

4. Bosabalidis A M. Ultrastructure, development and histochemistry of the polysaccharide-containing subcuticular compartments in Origanum dictamnus L. peltate glandular hairs. Flavour Fragr J. 2010; 25(4): 202-205. http://dx.doi.org/ 10.1002/ffj.1985

5. S c oula M, Kame nop oulos S. Origanum dictamnus L. and Origanum vulgare L. subsp. hirtum (Link) Ietswaart: traditional uses and production in Greece. In: Proc IPGRI Intern Workshop on oregano. Valenzano: Bari, Italy 1996: 26-32.

6. Chinou I, Liolios C, Moreau D, Roussakis C. Cytotoxic activity of Origanum dictamnus. Fitoterapia. 2007; 78(5): 342-344. http://dx.doi.org/10.1016/j.fitote.2007.02.005

7. Gortzi O, Lalas S, Chinou I, Tsaknis J. Evaluation of the antimicrobial and antioxidant activities of 
Origanum dictamnus extracts before and after encapsulation in liposomes. Molecules. 2007; 12(5): 932-945. http:// dx.doi.org/10.3390/12050932

8. Moller JKS, Lindberg Madsen H, Aaltonen T, Skibsted LH. Dittany (Origanum dictamnus) as a source of water-extractable antioxidants. Food Chem. 1999; 64(2): 215-219. http://dx.doi.org/10.1016/S0308-8146(98) 00143-5

9. Racanicci AMC, Danielsen B, Menten JFM, Regitano-d'Arce MAB, Skibsted LH. Antioxidant effect of dittany (Origanum dictamnus) in pre-cooked chicken meat balls during chill-storage in comparison to rosemary (Rosmarinus officinalis). Eur Food Res Technol. 2004; 218(6): 521-524. http://dx.doi.org/10.1007/s00217-004-0907-4

10. Bronner R. Simultaneous demonstration of lipids and starch in plant tissues. Stain Technol. 1975; 50(1): 1-4.

11. Taiz L, Zeiger E. Plant physiology. Sunderland, MA: Sinauer Associates, Inc.; 1998.

12. McCaskill D, Gershenzon J, Croteau R. Morphology and monoterpene biosynthetic capabilities of secretory cell clusters isolated from glandular trichomes of peppermint (Mentha piperita L.). Planta. 1992; 187(4): 445-454. http://dx.doi.org/10.1007/BF00199962

13. Kouri G, Tsimogiannis D, Bardouki H, Oreopoulou V. Extraction and analysis of antioxidant components from Origanum dictamnus. Inn Food Sci Emerg Technol. 2007; 8(2): 155-162. http://dx.doi.org/10. 1016/j.ifset.2006.09.003

\section{Włoski gruczołowe i mechaniczne Origanum dictamnus L. (Lamiaceae), $\mathrm{z}$ rośliny wykazującej dymorfizm sezonowy jako sposób przystosowania do stresu chłodu}

\section{Streszczenie}

Origanum dictamnus jest rośliną wykazującą dymorfizm sezonowy, która posiada inny wygląd zimą i latem. Pędy roślin zimowych pozbawione są liści z wyjątkiem ich strefy szczytowej, gdzie znajduje się kępka niewielkich liści pokrytych gęstym kutnerem utworzonym z włosków mechanicznych. Kutner ten w znacznym stopniu zapobiega przenikaniu zimna do mezofilu liści, w ten sposób pozwalając roślinom wytrzymywać niskie temperatury zimowe. Pędy roślin letnich charakteryzują się dużą siłą wzrostu i mają duże zielone liście. Włoski mechaniczne są dendroidalne i posiadają 5-komórkowy trzonek oraz kilka bocznych rozgałęzień. Włoski gruczołowe są dwojakiego rodzaju: duże włoski tarczowate i niewielkie włoski główkowate. Włoski tarczowate są liczne i składają się z 12-komórkowej główki, jednokomórkowego trzonka i bazalnej komórki epidermalnej. Stanowią one miejsca wydzielania olejku eterycznego. Włoski główkowate występują w niewielkiej liczbie i składają się z jednokomórkowej główki, jednokomórkowego trzonka oraz bazalnej komórki epidermalne. Nie wydzielają one olejku eterycznego, ale substancję hydrofilną. Olejek wydzielany przez włoski tarczowate posiada właściwości przeciwutleniające, przeciwdziała stresowi oksydacyjnemu wywołanemu niskimi temperaturami oraz przyczynia się do przystosowania się rośliny do stresu chłodu zimą.

Handling Editor: Elżbieta Weryszko-Chmielewska

This is an Open Access digital version of the article distributed under the terms of the Creative Commons Attribution 3.0 License (creativecommons.org/licenses/by/3.0/), which permits redistribution, commercial and non-commercial, provided that the article is properly cited.

CThe Author(s) 2014 Published by Polish Botanical Society 